\title{
EFFECT OF PSYCHOLOGICAL CAPITAL AND GRATITUDE ON SUBJECTIVE WELL-BEING YOUNG MOTHER OF HIJRAH COMMUNITIES IN JAKARTA
}

\author{
Akhmad Baidun ${ }^{1}$, Abdul Rahman Shaleh ${ }^{2}$, Miftahuddin ${ }^{3}$, Liany Luzvinda ${ }^{4}$, Desi Yustari \\ Muhtar \\ \{akhmad.baidun@uinjkt.ac.id ${ }^{1}$, abd.rahman.shaleh@uinjkt.ac.id ${ }^{2}$, miftahuddin@uinjkt.ac.id \}
}

Universitas Islam Negeri Syarif Hidayatullah Jakarta, Indonesia

\begin{abstract}
The purpose of this study was to prove the influence of psychological capital and gratitude to subjective well being on young mother of Jabodetabek Hijrah Community. This study involved 186 young mothers who had daughters or sons. The sampling was done using nonprobability sampling, specifically accidental sampling. The instruments used consisted of a Flourishing Scale (FS) and Scale for Positive and Negative Scales (SPANS), modified from Diener, Wirtz, Biswas- Diener, Tov, Kim-prieto, Choi, and Oishi [7], the Psychological Capital Questionnaire, 12 (PCQ-12) from Luthan, Youssef, and Avolio [4]. Testing the validity of the instrument, we used confirmatory factor analysis (CFA) and testing the hypothesis used multiple regression analyses. The results of the study prove that there was the influence of from psychological capital (self-efficacy, optimism, hope and resiliency) and gratitude towards subjective well being of the young mother of the Jabodetabek Hijrah Community. Based on coefficient regression testing indicated that 3 variables influenced subjective well being, i.e. optimism, hope, and a self of abundance. In this study, the proportion of variance of subjective well being explained by all independent variables was $22.3 \%$, while the remaining $77.7 \%$ was influenced by other variables outside of this study.
\end{abstract}

Keywords: Subjective Well being, Psychological capital, Gratitude, Jakarta Hijrah community.

\section{BACKGROUND}

The Hijrah community (after this referred to as Tasrah) is a fast-growing social community in Bandung and Jakarta within the past 5 (five) years. Beginning its activities since 2014, Tasrah focused on social activity and actively invited young mothers to emigrate through various studies. The study of science and activities like "Light of Jakarta" becomes a way for mothers to be told additional regarding Islam. As a Tasrah members besides developing ukhuwah, sharing knowledge and doing different positive activities. They invite people to change for the better personalities by exploring and active the teachings of Islam. Through Tasrah the young mothers are active in learning ukhuwah Islamiyah, knowing additional regarding their faith to induce happiness and awareness of the essence of life. Tasrah's positive results include together 
with young mothers feeling happier and additional prosperous once the change of integrity and being active in numerous activities.

Prosperity is a component of subjective well- being that every individual wants to achieve, such as a member of Tasrah. Busy life in big cities like Jakarta and Bandung makes people tense, feel depressed and experience psychological pressure. Individuals often feel helpless, less satisfied and shackled by routines. Thanks to activities in Tasrah, individuals can feel happiness and inner well-being. Research shows that psychological capital can affect stress [1] [2].

The recognition of young mothers who are Tasrah members in Jakarta who feel more comfortable and happy is a positive indication of Tasrah. Increasing the inner well-being of young mothers in Jakarta after participating in Tasrah's activities is interesting to study. The changes above are categorized as a process of migrating young Jakarta mothers in the millennial era.

Millennial Muslim emigration is a mental move that is moving from a bad inner atmosphere into a better inner atmosphere. Hijrah Tasrah is also only to seek the pleasure of Allah Ta'ala. The question is, what factors influence the happiness of Tasrah members?

Avey, Luthans, Smith, and Palmer [3] found that subjective well being is influenced by Psychological Capital. Psychological capital is a state of development of individual positive psychology characterized by self-efficacy, optimism, hope and resiliency [4].

Psychological capital helps develop and improve abilities and well-being [5]. If selfefficacy is high, individuals try to achieve their goals and believe they are ready to achieve them. People have the desire and produce many solutions to the matter (hope), make internal attribution and have positive expectations for an outcome (optimism), and respond absolutely and survive within the face of difficulty or resilience [3]. This often follows the conditions featured by young mothers.

Subjective well-being is also influenced by gratitude. Gratitude is a feeling that connects mental health and individual life satisfaction. Previous research shows that grateful individuals can experience a higher level of subjective well- being. Gratitude can enhance positive thinking, provide effective ways to deal with negative events and frustrate negative conditions such as depression [6]. Gratitude can be appreciated in the phrase "thank you" both to fellow human beings.

Research aims prove impact psychological capital and gratitude the subjective well-being Young Mothers within Hijrah community national capital Jakarta.

\section{THEORY AND HYPOTHESIS}

\section{Subjective Well Being}

According to Diener [7] subjective well-being could be an image of the level of experience of healthy people supported subjective evaluations. A subjective statement that is a part of quality life. A comprehensive assessment that refers to varied criteria. The description of life, each positive and negative emotions, includes judgments and feelings regarding life satisfaction. The conception of positive or negative feelings assessed through subjective evaluations. The Subjective Welfare dimension consists of cognitive and affective dimensions.

Cognitive assessment is that the analysis or individual evaluation of his life satisfaction which has world evaluation and evaluation specifically or domain [8]. Evaluation of life satisfaction generally could be a reflection of an individual's perception of his life and is influenced by the culture and the individual's view of positive life. Evaluation of life satisfaction 
specifically is an assessment created by an individual in evaluating bound dimensions of his life, as life with a partner and family [9].

Affective assessment is an analysis or an individual's evaluation of moods and emotions that are usually felt in his life [8] The dimensions of affective assessment are classified as an analysis of the existence of positive and negative effect. Positive effects are a combination of things that are arousing and fun things. High positive have an effect on happens once people feel high energy, full concentration, and pleasant involvement. Meanwhile, low positive have an effect on happens once people experience disappointment and fatigue [10]. The existence of positive emotions together with active, prepared and happy. The negative affect could be a combination of each arousal and unpleasantness. In negative affect there are emotions like anxiety, sadness, and fear. High negative affect on can arise when people feel anger, hatred, disgust, guilt, fear and anxiety [10].

Factors that influence subjective well-being are divided into two factors, particularly internal and external factors. Internal factors include self- esteem, temperament, psychological capital, and gratitude. External factors embrace Perceived Social Support and demographic factors.

The measurement of subjective well-being during this study custom-made the Flourishing Scale [7] therefore, the Scale of Positive and Negative expertise [7]. Flourishing Scale [7] was used to measure life satisfaction totaling 8 items as well as giving one psychological well-being score. The scale of the development of life happiness in general and life satisfaction specifically. In addition, the Scale of Positive and Negative affect scale [7] was also adopted to measure the affection domain, amounting to 12 items. Six positive affect experiences have an effect on the growth of feelings of happiness, enthusiasm, and strengthening attention. Six negative affect experiences have an effect on the growth of feelings of disappointment, anxiety, and irritability.

\section{Psychological capital}

Luthans, Youssef and Avolio [4] define psychological capital (PsyCap) is a state of individual psychological development and is characterized by: (1) having the confidence to take and make an effort needed for success in challenging tasks (self-efficacy); (2) making positive attributions about present and future success (optimism); (3) persevere in achieving goals and when needed directing the path to goals in order to succeed (expectations); and (4) when hit by problems and difficulties, able to survive and rise again and even greater to achieve success (resilience).

In this case, it is vital to know that psychological capital is the positive psychological states of people and not psychological traits [11]. The trait could be a comparatively permanent characteristic of a private, whereas the state involves the behavior, thoughts and actions that can be learned and developed by everybody. Luthans, Youssef and Avolio [4] conjointly explained that psychological capital could be a condition so that psychological capital will pass amendment over time, each increasing and decreasing. In contrast to ancient human and social capital, psychological capital can develop unceasingly over time [4]. Conjointly explains that psychological capital is seen as a quality which will be developed so that it will facilitate improve individual welfare [12].

Psychological capital has positive and vital effects on individual well-being. The results of an analysis conducted on academics in the Republic of South Africa show that psychological capital encompasses a significant relationship with the welfare of teachers [14]. In line with Cole, Daly, \& Mak [15], psychological capital has an influence on subjective well-being on unemployment. In individual entrepreneurs, found a positive relationship between psychological capital and subjective well-being of entrepreneurs. 
Measurement of psychological capital during this study uses PCQ-24 (validity analysis found by Luthan, Avolio, et al., [5], and Luthans, Youssef, \& Avolio, [4]). PsyCap has four aspects, each side consists of 6 items and a complete of every item is twenty-four items. The Psycap aspects are hope, self-efficacy, resilience and optimism. All items use a six-point Likert scale with a response of $1=$ strongly disagree to $6=$ strongly agree. Every item represents a scale setting before it is published and tested. Item hope was custom-made from Snyder and colleagues (1996). Samples of items from subscale hope are: "There are lots of ways around any problem," and "Right now I see myself as being pretty successful at work". Self-efficacy items are custom-made from Parker's [17] measure self-efficacy in work situations. Samples of selfefficacy items: "I feel confident that I can analyze weaknesses to find answers" and "I feel confident presenting information to a gaggle of colleagues".

Resilience items were custom-made from Wagnild and Young's [18], samples of resilience items: "I sometimes manage difficulties a technique or another at work," and "I feel I will handle several things at a time at this job." Optimism items were custom-made from Scheier and Carver's [19], samples of optimism items " I am optimistic regarding what is going to happen to me in the future as it works for working" and "I approach this job as if 'every cloud has a silver lining." Psychological capital in research It uses a Likert scale and uses a Psychological Capital Questionnaire form (PCQ-24) instrument developed by Luthans, Avolio, [5]. In keeping with four subscales, every subscale consists of six items with a total number of items that is twentyfour. Every subscale consists of self- efficacy, hope, optimism, and resilience.

\section{Gratitude}

Gratitude, may be taken as affective trait, mood, or emotion. Gratitude could be a general tendency to acknowledge and respond to emotions of gratitude for a variety of things that an individual experiences in life [20]. Gratitude may be conceptualized an effect on, behavior, or personality trait [21]. Gratitude is feeling and joy for what is received, whether that makes sense or not, whether it is concrete or abstract goodness [22]. Meanwhile, according to Bertocci \& Millard (in Emmons, \& McCullough, [20]) gratitude is an emotion, the essence of feeling happy about the benefits obtained. People who have gratitude admit that they did nothing to to induce rewards or benefits; he got it entirely as a present. Kant (in Emmons \& McCullough, [23]) defines gratitude as respecting somebody for the great he has done. Gratitude encompasses a vital impact on subjective well-being.

The gratitude scale utilized in this study could be a scale developed by researchers using the construct of gratitude theory from Al-Fauzan in his book which divides gratitude aspects into three aspects namely, gratitude with the guts, gratitude with the verbal, and gratitude with the member's body or gratefulness for deeds [24].

\section{Hypothesis}

Based on a theoretical study, the hypothesis of this research is "There could be a significant influence of psychological capital, gratitude on subjective well being".

\section{METHODE}

The population during this study were young mothers who are members of the Hijrah (Tasrah) Community in national capital Jakarta areas which were estimated to be 1.000 people. 
The sample of this study was 180 people. The method for taking sample research was used nonprobability sampling technique which was an accidental sampling technique.

The variables during this study were subjective well-being, psychological capital, and gratitude. Subjective well-being could be a description of the level of individual experience based on subjective evaluations of life both positive emotions and negative emotions including judgment and feelings about life satisfaction [7]. Psychological capital could be a positive psychological capacity possessed by every person that is beneficial in serving to people to develop things which have self-efficacy (self efficacy), positive expectations (optimism), hopes for achievement (hope), and resilience as expressed by Luthans, Youssef, and Avolio [4]. Gratitude could be a feeling of appreciation for the kindness that is received, not feeling short, knowing the contributions of others and appreciating simple pleasures [6].

The measuring instrument used to measure subjective well-being was a combination of a scale of FS (flourishing scale) and a scale of SPANE (Scale of positive and negative experience) with a complete variety of things of twenty items. The instrument used to measure psychological capital, particularly the Psychological Capital Questionnaire (PCQ-12) by Luthans et.al [5] which consists of twelve items that measure 4 dimensions of psychological capital, namely, selfefficacy, optimism, hope, and resilience. The gratitude instrument used measuring instruments from Watkins, Woodward, Stone \& Kolts [6] The Gratitude Resentment and Appreciation Test (GRAT).

Technical data analysis used multivariate analysis using SPSS 18.0 software system so as to (1) calculate the R-square quantity, which is the percentage (\%) dependent variable variance explained by independent variables; (2) calculate the significance of the impact of independent variables on the dependent variable, and (3) calculate the significance of the regression coefficients for every independent variable.

\section{Results}

\section{Testing the research hypothesis.}

First, used the R-square score to examine the quantity of variance proportions influencing the independent variable on the dependent variable. R- square gained was 0.223 (table 1); it suggests that the proportion of variance from Subjective Well being that being was explained by psychological capital and gratitude variables which were equal to $22.3 \%$, while the remaining $77.7 \%$ is influenced by other variables outside of this study.

\begin{tabular}{|c|c|c|c|c|}
\hline \multicolumn{5}{|c|}{ Model Summary } \\
\hline Model & $\mathrm{R}$ & R Square & Adjusted R Square & $\begin{array}{l}\text { Std. Enror of the } \\
\text { Estimate }\end{array}$ \\
\hline 1 & $.472^{2}$ & .223 & \begin{tabular}{r|}
.198 \\
\end{tabular} & 1.53508 \\
\hline
\end{tabular}

The second step is analyzing the impact of all independent variables on Subjective Well being. The results of the $F$ test of significance $(p<0.05)$ obtained that the significance of 0,000 (table 2), then the null hypothesis which states that there was no significant effect of all independent variables on Subjective Well being is rejected $(\mathrm{H} 0=$ rejected $)$. This result meant 
that there was a significant effect of Psychological Capital and Gratitude on Subjective Well being.

Table 2

Anova all Sample

ANOVA

\begin{tabular}{|ll|l|l|l|l|l|}
\hline & Model & \multicolumn{1}{c|}{$\begin{array}{c}\text { Sum of } \\
\text { Squares }\end{array}$} & \multicolumn{1}{c|}{ df } & Mean Square & F & \multicolumn{1}{c|}{ Sig. } \\
\hline 1 & Regression & 143.507 & 7 & 20.501 & 8.700 & $000^{2}$ \\
& Residual & 499.569 & 212 & 2.356 & & \\
Total & 643.076 & 219 & & & \\
\hline
\end{tabular}

a. Predictors: (Constant), PSYCHOLOGICAL CAPITAL, GRATIITUDE

b. Dependent Variable: SUBJECTIVE WELL BEING

The third step, namely testing the regression coefficients for each independent variable. If $\mathrm{p}<0.05$, then the variable regression coefficient becomes significant which meant that the independent variable had a significant impact on Subjective Well being.

\begin{tabular}{|c|c|c|c|c|c|}
\hline \multirow[b]{2}{*}{1} & \multirow{2}{*}{$\begin{array}{l}\text { Unstandardized } \\
\text { coefficients } \\
\text { B }\end{array}$} & \multicolumn{2}{|c|}{$\begin{array}{l}\text { Standardized } \\
\text { coefficients }\end{array}$} & \multirow[t]{2}{*}{$t$} & \multirow[t]{2}{*}{ Sig. } \\
\hline & & Std. Error & Beta & & \\
\hline (Constant) & 34.682 & 3.951 & & & .000 \\
\hline Hope & .050 & .050 & .075 & 1.016 & 311 \\
\hline Optimism & .127 & .037 & .231 & 3.408 & .001 \\
\hline resilience & .107 & .045 & .168 & 2.394 & .018 \\
\hline Self efficacy & .005 & .036 & .009 & .136 & 892 \\
\hline Self of abbundance & 103 & 023 & 281 & 4.422 & 000 \\
\hline Appreciation for others & .013 & .34 & .024 & 375 & .708 \\
\hline Simple Appreciation & .004 & .042 & .006 & .102 & 919 \\
\hline
\end{tabular}

Based on the regression equation (table 3) we found that psychological capital and gratitude affect subjective well-being and the significance of the influence of each independent variable on the dependent variable. The formula of the regression equation influences psychological capital subjective well-being as follows:

$\mathrm{SWB}=34.682+0.050$ hope +0.127 Optimism

+0.107 Resiliency -0.005 self efficacy

+0.103 self of abundance +0.103 appreciation for others -0.004 simple appreciation.

While the significance of the influence of each independent variable on the dependent variable for hope (0.311), optimism (0.001), resilience (0.018), self-efficacy (0.892), self of abundance (0.000), appreciation for others (0.708) and simple appreciation (0.919). The dimensions of optimism $(0.001)$ and resilience $(0.018)$ in the psychological capital variable, as well as the dimensions of self of abundance $(0,000)$ on the variable gratitude, had a significant effect on subjective well-being. Whereas the hope dimension (0.311) and self- efficacy (0.892) 
on psychological capital, as well as an application for others $(0.708)$ and simple appreciation (0.919) on the gratitude variable, the effect was not significant on subjective well- being.

Testing the proportion of variance aims to calculate the significance of the incremented proportion of each independent variable to the dependent variable. The result was the proportion of variance of each independent variable to the dependent variable could be seen in table 4 .

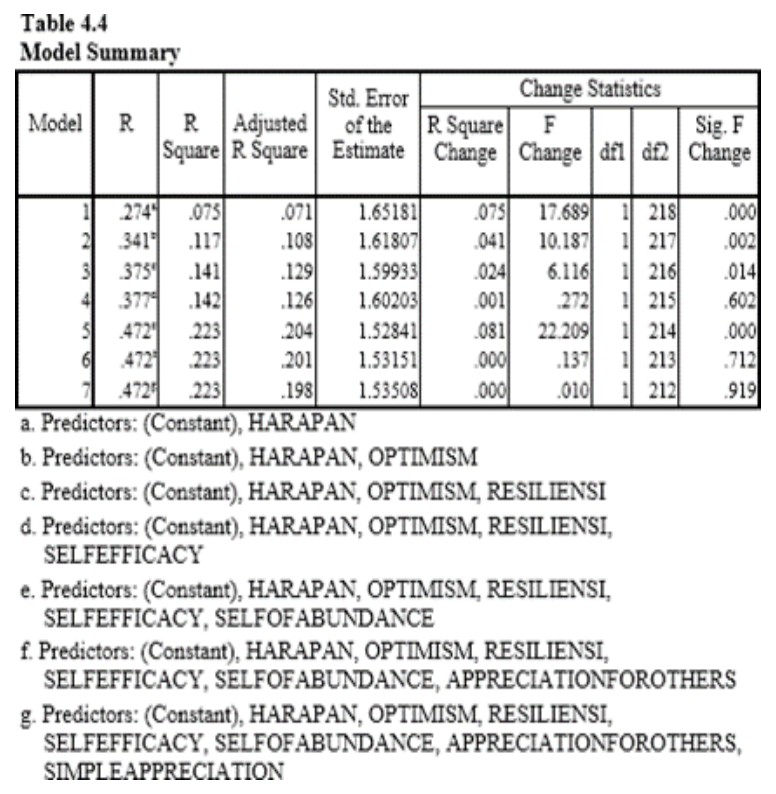

Based on table 4 it could be concluded as follows:

1. Hope had a significant impact on Subjective Well being (significance 0,000) and its contribution to Subjective Well being was $7.5 \%$ (R-square change 0.075 ).

2. Optimism had a significant impact on Subjective Well being (significance 0.002) and its impact on Subjective Well being was 4.1\% (R-square change 0.041).

3. Resilience had a significant impact on Subjective Well being (significance 0.014) and its contribution to Subjective Well being was $2.4 \%$ (R-square change 0.024 ).

4. Self-efficacy had no significant impact on Subjective Well being (significance 0.602) and the contribution of its impact on Subjective Well being was $0.1 \%$ (R-square change 0.001 ).

5. Self of abundance had a significant impact on Subjective Well being (significance 0,000) and its contribution to Subjective Well being was $8.1 \%$ (R-square change 0.081).

6. Appreciation for others had no significant impact on Subjective Well being (significance 0.712) and the contribution of its impact on Subjective Well being was $0,00 \%$ (R-square change 0,000$)$.

7. Simple appreciation had no significant impact on Subjective Well being (significance 0.919 ) and the contribution of its impact on Subjective Well Being was $0,00 \%$ (R-square change 0,000$)$. 


\section{DISCUSSION}

The The results showed that the psychological capital variable had a significant effect on subjective well- being. This finding is supported by observations and interviews which found that young mothers have a large personal capacity and willingness to ensure that they get wellbeing. The results of this research on psychological capital are in line with the research of Ciarocci and Deneke which explains that psychological capital significantly influences subjective well-being [25]. Research by Parker's, et al. [17] suggests that multilevel structural equation modeling shows that psychological capital is significantly related to psychological and social welfare.

Optimism (0.001) and Resiliency (0.018) have a significant effect, whereas dimensions of expectations (0.311) and self-efficacy (0.892) on the psychological capital variable the effect is not significant on subjective well-being. This happens, because happiness is essentially an individual's perception or outlook on life when assessing life. As a result, the concept or feeling of happiness of each person is different according to their perception.

The variable gratitude has a positive and significant effect on subjective well-being. This is in line with Chan's [26] study in Hong Kong regarding gratitude which is positively correlated with subjective well-being. Park, Peterson \& Seligman [27] conducted a survey of 5229 adults and found that individual characters such as gratitude consistently and strongly affected life welfare. Individuals who have low gratitude tend to pay less attention to others, feel more disrespected and loved by others [27].

A study by Algoe [28] concluded that grateful individuals will be more positive and motivated to develop and maintain relationships. People who are grateful tend to be easily accepted and loved by others.

Individuals who have low gratitude tend to pay less attention to others and are reluctant to interact with others. They feel more unappreciated and loved by others [20]. Individuals with a low ability to be grateful have difficulties to have a satisfying relationship and experience loneliness.

Self of abundance has a significant effect $(0,000)$, whereas effect of appreciation for others dimensions (0.708) and simple appreciation (0.919) on gratitude variables on subjective wellbeing was not significant.

The effect of appreciation for others on subjective well-being is not significant, it is possible that Indonesian culture avoids riya 'by giving direct praise.

The effect of simple appreciation on subjective well-being is insignificant, probably because young mothers are still thinking about the need for material to meet their needs, so the appreciation of what they have is still not strong.

\section{DISCUSSION}

Based on the results of research data analysis, the conclusions that can be taken are; "There is a significant effect together of psychological capital and gratitude variables on the subjective well-being of young mothers in the Hijrah Community in Jakarta". Based on the regression coefficients of each independent variable, it was found that hope, optimism, and resilience in the psychic variables and self of abundance in the gratitude variable had a significant effect on subjective well being. Whereas self-efficacy on variable psychological capital; and appreciation 
for others and simple appreciation on the gratitude variable has no significant effect on subjective well being.

Based on variance proportions, subjective well-being that was influenced by independent variables simultaneously using $\mathrm{R}$-square gained was 0.223 ; it meant the proportion of variance from Subjective Well being was explained by psychological capital and gratitude variables which were equal to $22.3 \%$, while the remaining $77.7 \%$ was influenced by other variables outside of this study. Future studies are suggested to involve other predictors such as demographics, spirituality, knowledge and attitudes.

The current research population was only in the Tasrah Jakarta community with the proportion of the overall independent variable variance to subjective well-being only $22.3 \%$. Future studies are suggested to expand population coverage in various other large cities. 


\section{References}

[1] Riolli, L, Savicki, V, \& Richards, J.: Psychological capital as a buffer to student stress. Psychology. 3 (12A):1202-1207. (2012). http://dx.doi.org/10.4236/psych.312A178.2012.

[2] Yu Wen, M.L, Chuan Lin, D.Y.: Does Psychological Capital Combat Learning and Adaptive Stress of College Freshmen. Journal of studies in Education; ISSN (Online): 2162- 6952, 4(1): 25-42. (2014).

[3] Avey, J. B., Luthans, F., \& Youssef, C. M.: The additive value of positive psychological capital in predicting work attitudes and behaviors. Journal of Management, 36, 430-452. (2010).

[4] Luthans F, Youssef CM, Avolio BJ.: Psychological capital. New York: Oxford University Press. (2007a).

[5] Luthans, F., Avolio, B.J., Avey, J.B. \& Norman, S.M.: Positive psyhcological capital: measurement and relationship with performance and satisfaction. Personel Psychology. 60(3), 541-572. (2007b).

[6] Watkins, P. C., Woodward, K., Stone, T., \& Kolts, R. L.: Grattitude and Happiness; Development of A Measure of Grattitude, and Relationship With Subjective Well being. Social Behaviour and Personalty, 31(5): 431-452. (2003).

[7] Diener, E., Wirtz, D., Tov, W., Kim-Prieto, C., D, C., Oishi, S., \& Biswas-Diener, R. : New measures of well-being: Flourishing and positive and negative feelings. Social Indicators Research, 39: 681-716. (2009).

[8] Ed Diener, E. M., Lucas, R. E., \& Smith, H. L.: Subjective Well Being: Three Decades of Progress. Psychological Bulletin. (1999).

[9] Ed Diener, Chan, M. E.: Happy People Live Longer: Subjective Well-Being Contributes to Health and Longevity. Applied Psychology: Health And Well-Being. (2011).

[10] Watson, D., Clark, L. A., \& Tellegen, A.: Development and validation of brief measures of positive and negative affect: The PANAS scales. Journal of Personality and Social Psychology. (1988).

[11] Envick BR.: Beyond human and social capital: The importance of positive psychological capital for entrepreneurial success. Entrepreneurial Executive 10: 41-52. (2005).

[12] Froman, L. (2010). Positive psychology in the workplace. Journal of Adult Development, 17(2), 5969.

[13] Culbertson, S. S., Fullagar, C. J., \& Mills, M. J. (2010). Feeling good and doing great: The relationship between psychological capital and well-being. Journal of Occupational Health Psychology, 15(4), 421-433.

[14] Hansen, A., Buitendach, J.H., Kanengoni, H.: Psychological capital, subjective well-being, burnout and job satisfaction amongst educators in the Umlazi region in South Africa. SA Journal of Human Resource Management. (2015).

[15] Cole, K., Daly, A., \& Mak, A.: Good for the soul: The relationship between work, wellbeing and psychological capital. The Journal of Socio-Economics. (2009).

[16] Baron, C., Boiral, O., \& Gunnlaugson, O. (2013). Environmental Leadership and Consciousness Development: A Case Study Among Canadian SMEs. Journal of Business Ethics, 123(3), 363-383.

[17] Parker, P. D., Ciarrochi, J., Heaven, P., Marshall, S., Sahdra, B., \& Kiuru, N.: Hope, Friends, and Subjective Well-Being: A Social Network Approach to Peer Group Contextual Effects. Child Development, Volume 00, Number 0, 1. (2014).

[18] Wagnild, G. M., \& Young, H. M.: Development and psychometric evaluation of the Resilience Scale. Journal of Nursing Measurement, 1(2), 165-178. (1993).

[19] Scheier, M. F., \& Carver, C. S.: Optimism, coping, and health: Assessment and implications of generalized outcome expectancies. Health Psychology. (1985).

[20] McCullough, Michael E.,Emmons, Robert A.,Tsang, Jo-Ann.: Journal of Personality and Social Psychology, Vol 82(1), 112-127. Jan (2012).

[21] Wood, A. M., Joseph, S., \& Linley, P. A.: Coping style as a psychological resource of grateful people. Journal of Social and Clinical Psychology. (2007).

[22] Emmons, R.A. \& Hill, J. Words of gratitude for mind, body, and soul. Radnor, PA: Templeton Foundation Press. (2001). 
[23] Emmons, R. A.: The Psychology of Gratitude: An Introduction. In R. A. Emmons \& M. E. McCullough (Eds.), Series in affective science. The psychology of gratitude. Oxford University Press. (2004).

[24] Al-Fauzan, S. (2005). Indahnya bersyukur: Bagaimana meraihnya ? Bandung: Marja.

[25] Ciarocci, J. W., \& Deneke, E.: Hope, Optimism, Pessimism, And Spirituality As Predictors Of WellBeing Controlling For Personality. Research in the Social Scientific Study of Religion, Vol. 16, 162183. (2006).

[26] Chan, D. W.: Subjective well-being of Hong Kong Chinese teachers: The contribution of gratitude, forgiveness, and the orientations to happiness. Teaching and Teacher Education, 32: 22-30. (2013).

[27] Park, N., Peterson, C., \& Seligman, M. E. P.: Strengths of character and wellbeing. Journal of Social and Clinical Psychology, 23, 603-619. (2004).

[28] Algoe, S. B., Haidt, J., \& Gable, S. L.: Beyond Reciprocity: Gratitude and Relationships in Everyday Life. National Institutes of Health , 8(3): 425-429. (2008). 